\title{
Square Wave Voltammetry for Analytical Determination of Cadmium in Natural Water Using $\mathrm{Ca}_{10}\left(\mathrm{PO}_{4}\right)_{6}(\mathrm{OH})_{2}$-Modified Platinum Electrode
}

\author{
Moulay Abderrahim El Mhammedi ${ }^{{ }^{*}}$, Mounia Achak ${ }^{2}$, Mina Bakasse ${ }^{3}$ \\ ${ }^{1}$ Equipe de Chimie Anlaytique et Modélisation Statistique, Faculté Polydisciplinaire, \\ Université Hassan $1^{\text {er }}$, Khouribga, Morocco \\ ${ }^{2}$ Laboratoire d' Hydrobiologie et d' Algologie, Faculté des Sciences Semlalia, \\ Université Cadi Ayyad, Marrakech, Morocco \\ ${ }^{3}$ Equipe d'Analyse des Micro-Polluants Organiques, Faculté des Sciences, \\ Université Chouaib Doukkali, El Jadida, Morocco \\ E-mail:elmhammedi@yahoo.fr \\ Received June 29, 2010; revised August 2, 2010; accepted October 26, 2010
}

\begin{abstract}
This paper reports on the development of a novel electrochemical assay for cadmium (II) in natural water, which involves the use of disposable hydroxyapatite modified platinum electrode (HAP/Pt). Cadmium (II) was preconcentrated on the surface of the modified electrode and adsorbed onto HAP and oxidized at $\mathrm{E}=$ $-680 \mathrm{mV}$. The HAP-modified platinum electrode exhibited superior performance in comparison to the platinum electrode and surprisingly, yielded a higher electrochemical response. The best defined anodic peak was obtained with $0.2 \mathrm{~mol} \mathrm{~L}^{-1} \mathrm{KNO}_{3} \mathrm{pH} 5.0$ after $25 \mathrm{~min}$ of accumulation time. Using these conditions, the calibration plot was linear over the range $1 \times 10^{-8}$ to $5 \times 10^{-6} \mathrm{~mol} \mathrm{~L}^{-1} \mathrm{Cd}^{2+}$. The precision was examined by carrying out eight replicate measurements at a concentration of $2.5 \times 10^{-5} \mathrm{~mol} \mathrm{~L}^{-1}$; the coefficient of variation was $2.9 \%$. The method was applied to the determination of the analyte in river water samples. The interfereence of other metal ions on the voltammetric response of Cd(II) was studied. The HAP films was clearly observed in the SEM images and characterized by X-ray diffraction, IR spectroscopy and chemical analysis.
\end{abstract}

Keywords: Hydroxyapatite, Cadmium, Platinum Electrode, Square Wave Voltammetry

\section{Introduction}

Heavy metals such as lead, cadmium and mercury are rapidly increasing continuously to an alarming level, particularly in rivers and near shore waters where industrial wastes are being discharged. They tend to concentrate in all matrices in the environment [1]. Mining, pouring, casting, processing, and metals use have led to their dispersion into the general environment. Ingestion of food and beverages contaminated with heavy metals can impair the health of the general population [2]. In this context, heavy metals have been extensively investigated. Procedures related to atomic adsorption spectrometry (AAS) [3,4], atomic emission spectrometry (AES) [5] and ion chromatography techniques [6,7] have been published. However, these techniques have some disadvantages, such as complicated operation, high cost of maintenance, expensive apparatus requiring well- controlled experimental conditions.

More specifically, the electrochemical detection of heavy metals has been performed on different electrode surfaces, including solid electrodes [8,9], Nafion-modified electrodes, [10] and microeletrodes [11]. Several researchers have reported the use of chemically modified electrodes (CMEs) in electroanalysis, using pulse techniques such as square-wave voltammetry, and differenttial pulse voltammetry [12]. This electroanalytical technique is thus less sensitive to the effects of matrix interferences, a property which characterizes its success in electroanalysis [13]. CMEs have several advantages such as low background current, wide range of usable potential, rapid renewability and easy fabrication $[14,15]$. Electrochemical methods of analysis occupy one of the leading places among other methods of analytical chemistry. This is favored by the well-developed theory and 
modern instrumentation based on microprocessor and computer facilities. Electrochemical methods allow researchers to study and determine both macro and trace amounts of inorganic and organic compounds in the assay of the basic substance and in the analysis of impurities respectively.

Mercury-based electrodes, especially mercury-film electrodes, have been widely used in anodic stripping voltammetry [16,17] for cadmium determination [18]. The formation of an amalgam enables the analyte to be accumulated in the mercury film, thus providing the stripping with high sensitivity and reproducibility. However, because of the toxicity of mercury, it is important to develop mercury-free electrodes for voltammetric stripping determination of cadmium.

For trace element concentrations, adsorption is the most common method and research has focussed on natural adsorbents, either organic or mineral $[19,20]$. Hydroxyapatite $\left(\mathrm{Ca}_{10}\left(\mathrm{PO}_{4}\right)_{6}(\mathrm{OH})_{2}\right)$, the main component of bones and teeth, attracts considerable interests in many areas because of acid-base properties, ion-exchange ability, and adsorption capacity [21].

Many studies have recognized the ability of hydroxyapatite (HAP) to bind divalent heavy metal ions. Previous studies have shown that synthetic HAP has a high removal capacity for $\mathrm{Pb}, \mathrm{Zn}, \mathrm{Cu}, \mathrm{Cd}, \mathrm{Co}$, and $\mathrm{Sb}$ from aqueous solutions [22-31].

In the work discussed in this paper, the advantages of using HAP-modified platinum electrode combined with square-wave voltammetry were explored to establish an appropriate method for analytical determination of cadmium (II) in pure and natural water samples. The interference of some common heavy metal ions, such as $\mathrm{Cu}(\mathrm{II}), \mathrm{Zn}(\mathrm{II})$ and $\mathrm{Pb}(\mathrm{II})$ was investigated. The performance of analytical method and the HAP/Cd(II) interaction were investigated using cyclic voltammetry, square wave voltammetry and electrochemical impedance spectroscopy. Some experiment conditions were optimized and a voltammetric method for determination of cadmium (II) in natural water was proposed and the result was satisfactory. This method was convenient and available because of its higher sensitivity, lower detection limit and low costs.

\section{Experimental}

\subsection{Reagents}

All chemicals were reagent grade and were used as received. Aqueous solutions were prepared by dissolving a certain amount of chemicals into high-purity Bi-distilled deionized (BDW) water (MilliQ water system). Cadmium nitrate and potassium nitrate were purchased from Fisher Scientific. Carbon paste was supplied from (Car- bone, Lorraine, ref 9900, French). Hydroxyapatite used in this work was synthesized by an aqueous solution route involving mixing calcium nitrate and ammonium phosphate [32]. In each experiment, the total sample volume in the electrochemical cell was $20 \mathrm{~mL}$.

\subsection{Apparatus}

The coated specimen was examined using a scanning electron microscope (SEM, Jeol JSM-5500). One coated specimen was investigated by inductively coupled plasma-atomic emission spectrometry (ICP-AES, PerkinElmer DV 3300) analysis.

The powder produced in this study was analyzed with an X-ray diffraction (XRD) diffractometer (Philips PW 1710 power $\mathrm{X}$-ray diffractometer) using $\mathrm{Cu} \mathrm{K}$ radiation $(\mathrm{K} 1=0.15406 \mathrm{~nm} ; \mathrm{K} 2=0.1 .5444 \mathrm{~nm})$. The detector was scanned between $10^{\circ}$ and $70^{\circ}$ angles with a step size of $0.02^{\circ} \mathrm{s}^{-1} 2 \theta$. The identification of phases was achieved by comparing the diffraction pattern obtained for the powder and comparing their diffraction patterns with the standard cards on the ICDD-JCPDS database $(* 09-0432 *)$ for hydroxyapatite [33]. The powdered sample was tested after calcination. A Fourier transform infrared (FTIR) spectrum of the synthesized HAP was obtained using a 1700 FTIR spectrometer. Spectra were obtained in the mid-infrared region $\left(4000-400 \mathrm{~cm}^{-1}\right)$.

Voltammetric measurements were performed with a voltalab potentiostat (model PGSTAT 100, Eco Chemie B.V., Utrecht, The Netherlands) driven by the general purpose electrochemical systems data processing software (voltalab master 4 software) connected to a Pentium III computer run under windows 98. The electrochemical equipment consisted of glass cell containing a HAP modified platinum electrode, a platinum counter electrode and $\mathrm{Ag} / \mathrm{AgCl} / 3 \mathrm{M} \mathrm{KCl}$ reference electrode. The pH-meter (Radiometer Copenhagen, PHM210, Tacussel, French) was used for adjusting $\mathrm{pH}$ values.

\subsection{Substrat Preparation and Electrodeposition of HAP}

The platinum plate was abraded with silicon carbide paper in successive grades from 400, 600 to 1200 grit (Leco Corporation, MI) and then ultrasonically cleaned in bi-distilled water and dried, degreased with AR grade ethanol and acetone, and rinsed with double distilled water before use. The equipment for electrodeposition of HAP consisted of a glass cell containing the HAP suspension, a platinum substrate electrode and a platinum counter electrode. The separation distance between electrodes was $2 \mathrm{~cm}$. Electrodeposition process was carried out at a constant voltage of $14.5 \mathrm{~V}$ for $24 \mathrm{~h}$. After the 
electrodeposition process, the coated platinum substrate was removed from the suspension and was dried at room temperature.

\subsection{Physico-chemical Characterization of Electrodeposit}

Scanning electron microscopy (SEM) was used to observe the morphology of samples. The coating formed on platinum support was characterized by X-ray diffraction (XRD) and Fourier transform infrared spectroscopy (FTIR). ICP-AES permitted also the quantitative determination of $\mathrm{Ca}$ and $\mathrm{P}$.

\subsection{Analytical Procedure}

The electrode was first immersed in a preconcentration solution containing the cadmium ions, where the accumulation of cadmium ions was achieved chemically by binding to hydroxyapatite at open circuit. The electrode was then removed from the accumulation cell, rinsed with water, and transferred to the separate voltammetric cell containing only a supporting electrolyte $\left(0.2 \mathrm{~mol} \mathrm{~L}^{-1}\right.$ $\mathrm{KNO}_{3}$ ). The same procedure was carried out in sample analysis and all electrochemical experiments were carried out at room temperature.

The HAP modified platinum electrode (HAP/Pt) was characterized by impedance spectroscopy (EIS). This measurement was carried out with the same electrochemical system described above before and after immersion in solution containing cadmium (II) ions. The frequencies between $100 \mathrm{kHz}$ and $10 \mathrm{MHz}$ can be measured with AC amplitude of 5-10 mV at $0 \mathrm{mV}$. Computer programs automatically controlled the measurements performed at rest potentials after $30 \mathrm{~min}$ of exposure. The impedance diagrams are given in the Nyquist representation. The charge-transfer resistance $\left(\mathrm{R}_{\mathrm{t}}\right)$ values are calculated from the difference in impedance at lower and higher frequencies, as suggested by Tsurus et al. [34]. The double-layer capacitance $\left(\mathrm{C}_{\mathrm{dl}}\right)$ and the frequency at which the imaginary component of the impedance is maximal $\left(-Z_{\max }\right)$ are found as represented in the equation:

$$
\mathrm{C}_{\mathrm{dl}}=1 / \omega \mathrm{R}_{\mathrm{t}} \text { were } \omega=2 \pi \mathrm{f}_{\max }
$$

After accumulation step, the electrodeposit layer was analyzed at carbon paste electrode (CPE) by cyclic voltammetry. The carbon paste was prepared by hand mixing of high purity graphite powder with HAP in weight ratio 1:1.

Experiments were conducted using the square-wavevoltammetry technique by deposition of the target cadmium (II) at open circuit. The accumulated metal was then anodically oxidised at the potential ranging from
-1.0 to $-0.4 \mathrm{~V}$ using a step potential of $25 \mathrm{mV}$; amplitude $5 \mathrm{mV}$ and duration $5 \mathrm{sec}$ at scan rate $1 \mathrm{mV} \mathrm{s}^{-1}$.

After the optimization of the voltammetric parameters, analytical curves were obtained in pure electrolyte by the standard addition method for cadmium (II). The standard deviation of the mean current $(\sigma)$ was measured at the oxidation potential of cadmium for seven voltammograms of the blank solution in pure electrolytes for the determination of the quantification limit (QL, 3 $\sigma$ ) and the detection limit (DL, 10б) together with the slope of the straight line of the analytical curves. The method of standard additions was used for analysis of real samples, by spiking with appropriate amounts of standard Cd(II) solution. All measurements were taken at room temperature.

\section{Results and Discussion}

\subsection{Electrode Synthesis}

Figure 1 shows SEM micrograph of the calcium phosphate coating obtained at a potential of $E=14.5 \mathrm{~V}$. It was observed that the powder layer exhibited a porous microstructure with micropores which were relatively well separated and homogeneously distributed over the surface.

The $\mathrm{Ca} / \mathrm{P}$ ratio deduced from ICP-AES analysis is: $\mathrm{Ca} / \mathrm{P}=1.67$. This $\mathrm{Ca} / \mathrm{P}$ ratio value corresponds to a stochiometrc Ca-hydroxyapatite. This was confirmed by the XRD pattern (Figure 2) which shows the typical diffraction peaks at $25.8^{\circ} \sim 31.6^{\circ} \sim 32.1^{\circ} \sim 32.7^{\circ}$ and $34^{\circ}$ corresponding to the Ca-HAP as indicated in Joint Committee on Powder Diffraction Standards card no. 09-0432. It should be noted that the development of refined HAP was not the only prime objective of the present work but

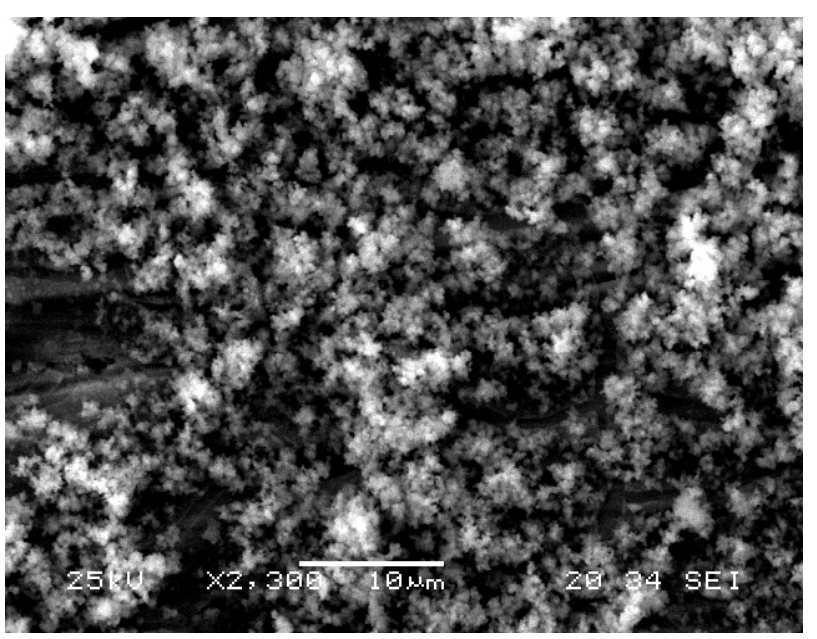

Figure 1. Scanning electron micrograph of apatite/platinum. 


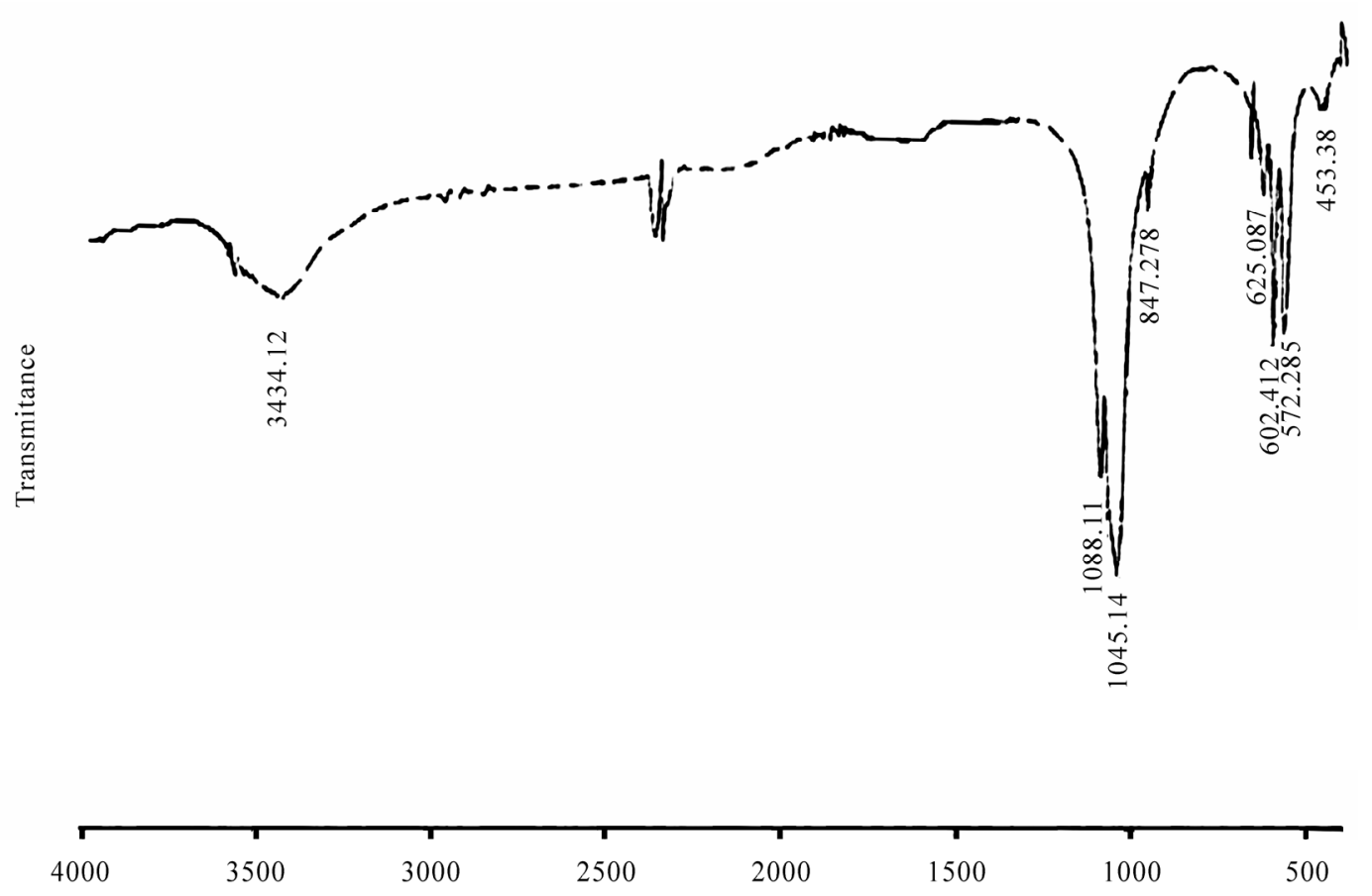

Figure 2. IR spectra of the apatite deposed on the platinum surfaces after analysis at $900^{\circ} \mathrm{C}$ for $3 \mathrm{~h}$.

to develop an adsorbent calcium phosphate coating with high activity.

The IR spectra of the investigated HAP powder (Figure 3) shows the typical absorption bands related to the modes of phosphate $\left(470 \mathrm{~cm}^{-1} ; 565 \mathrm{~cm}^{-1} ; 960 \mathrm{~cm}^{-1}\right.$; $\left.1035 \mathrm{~cm}^{-1}\right)$, hydroxyl $\left(3570 \mathrm{~cm}^{-1}\right)$ and water $\left(1635 \mathrm{~cm}^{-1}\right.$; $3410 \mathrm{~cm}^{-1}$ ).

\subsection{Voltammetric Characteristics}

Figure 4 shows the uptake of cadmium (II) by the HAP-modified platinum electrode (HAP/Pt). The volt ammograms were obtained by using cyclic voltammetry (CV) at an effective scan rate of $100 \mathrm{mV} \mathrm{s}^{-1}$. The base curve, which shows no peak, was obtained with HAP/Pt before preconcentration step in $\mathrm{Cd}(\mathrm{II})$ solution. As it can be seen from Figure 4(b), the peak current appeared after the preconcentration step, manifesting the uptake of $\mathrm{Cd}$ (II) by HAP-modified platinum electrode from bulk solution.

\subsection{Electrochemical Impedance Spectroscopy}

Figure 5 shows the impedance diagram for HAP-modified platinum electrode (HAP/Pt) before and after preconcentration step in $3 \times 10^{-4} \mathrm{~mol} \mathrm{~L}^{-1}$ cadmium (II) solution. Similar Nyquist diagrams were obtained in $0.2 \mathrm{~mol} \mathrm{~L}^{-1}$ $\mathrm{KNO}_{3}$ electrolyte. The parameters associated with the diagrams impedance are given in Table 1, as it can be seen from the figure, the Nyquist plots contain depressed semi-circles with the centre under the real axis; this kind of phenomenon is known as dispersing effect. It appears clearly from these data that the capacitance at the interface increases when the HAP/Pt is exposed to cadmium (II). This observation is in agreement with the literature in the case of adsorption phenomenon at the electrode surface. Our result gives another evidence for $\mathrm{Cd}(\mathrm{II})$ adsorption on the HAP layer as part of an integrated process leading to the electrolytic reduction of the heavy metal at the modified surface. The observed decrease of the charge-transfer resistance means also that the modified electrode becomes more conductive, which can be explained by the presence of cadmium on the electrode surface.

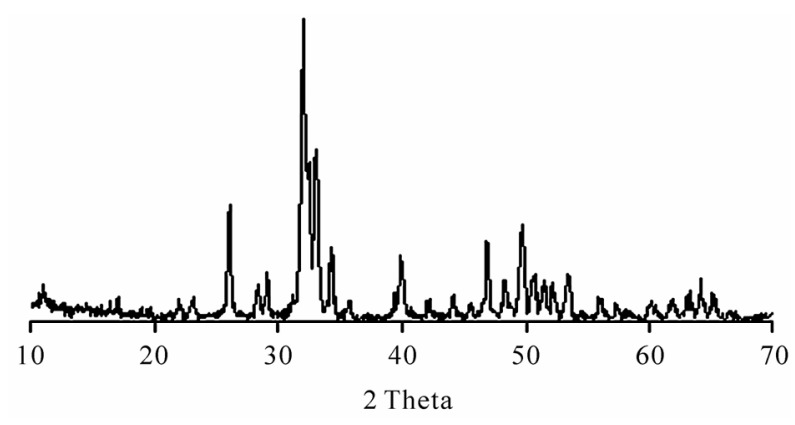

Figure 3. XRD of hydroxyapatite layer on platinum surfaces, calcined at $900^{\circ} \mathrm{C}$ for $3 \mathrm{~h}$. 


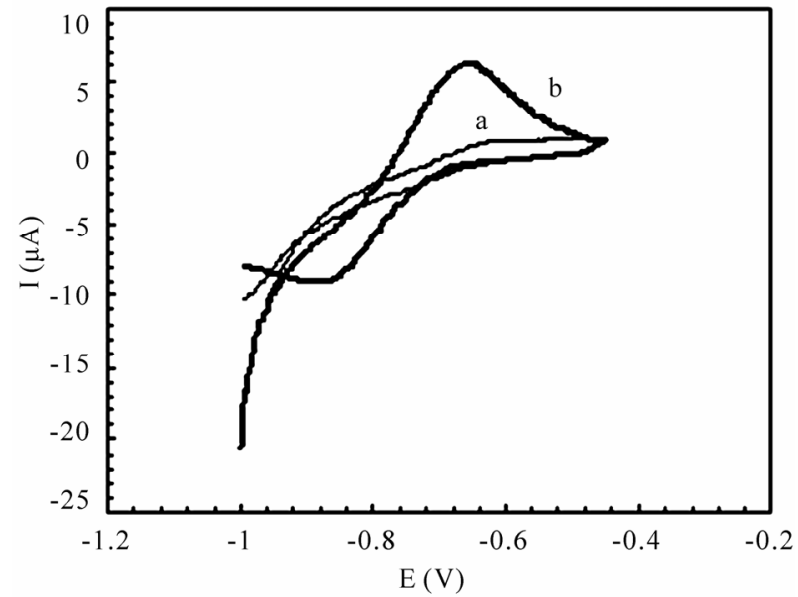

Figure 4. Cyclic voltammogram of HAP modified platinum electrode: (a) before any contact with cadmium (II), (b) after incubation with cadmium (II) species during $\mathbf{3 0}$ min; supporting electrolyte is $0.2 \mathrm{~mol} \mathrm{~L}^{-1} \mathrm{KNO}_{3}$, pH 5.6; the scan rate was $100 \mathrm{mV} \mathrm{s}^{-1}$. [Cd(II)] $=3 \times 10^{-4} \mathrm{~mol} \mathrm{~L}^{-1}$.

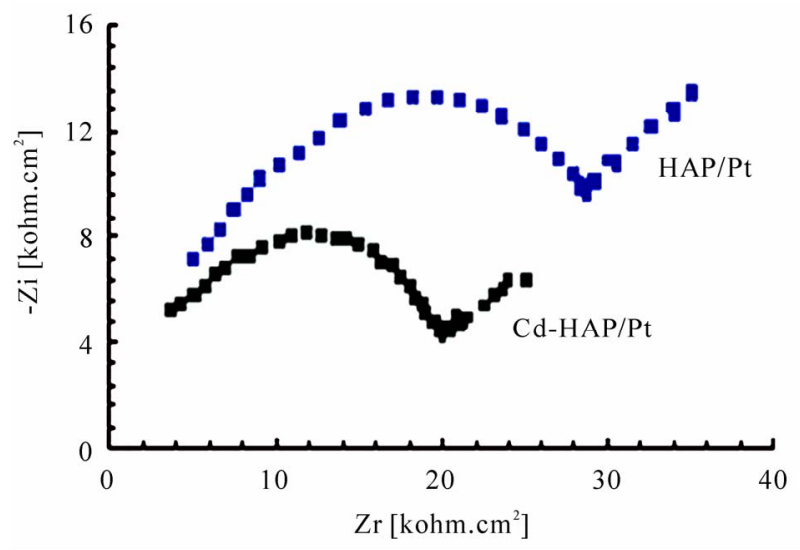

Figure 5. Impedance spectra at $0 \mathrm{~V}$ of HAP modified platinum electrode (a) before any contact with cadmium (b) after preconcentration in cadmium (II) solutions. Conditions are as described in Figure 4.

Table 1. Electrical parameters calculated from the impedance spectra in $0.2 \mathrm{~mol} \mathrm{~L}^{-1} \mathrm{KNO}_{3}$ for the $\mathrm{HAP} / \mathrm{Pt}$ and HAP/Pt-Cd(II) solution interfaces.

\begin{tabular}{lccc}
\hline & $\mathrm{R}_{\mathrm{e}}\left(\mathrm{Kohm} . \mathrm{cm}^{2}\right)$ & $\mathrm{R}_{\mathrm{ct}}\left(\mathrm{kohm} . \mathrm{cm}^{2}\right)$ & $\mathrm{C}_{\mathrm{dl}}\left(\mathrm{pF} / \mathrm{cm}^{2}\right)$ \\
\hline $\mathrm{HAP} / \mathrm{Pt}$ & 2.831 & 30.94 & 205.7 \\
$\mathrm{Cd}-\mathrm{HAP} / \mathrm{Pt}$ & 0.9 & 21.27 & 236.3 \\
\hline
\end{tabular}

\subsection{Voltammetric Analysis of HAP Layer}

Before and after the preconcentration step in cadmium solution, the deposit powder on platinum surfaces was analyzed at carbon paste electrode (CPE) by cyclic voltammetry (Figure 6). No peaks were observed for $\mathrm{HAP}$ layer in the potential range -0.4 to $-11.0 \mathrm{~V}$ (vs. $\mathrm{Ag} / \mathrm{AgCl} / 3 \mathrm{M} \mathrm{KCl})$ in $1.0 \mathrm{~mol} \mathrm{~L}^{-1} \mathrm{HClO}_{4}$ electrolyte before the accumulation step (curve a). As shown in Figure 6(b), a pair of stable and well-defined redox peaks was observed for $\mathrm{HAP} / \mathrm{Cd}(\mathrm{II})$. This result confirms the presence of $\mathrm{Cd}(\mathrm{II})$ into or/and into apatite coating platinum electrode after preconcentration in cadmium solution. The result demonstrates that the HAP plays an important role in the accumulation process of $\mathrm{Cd}(\mathrm{II})$ on the platinum electrode surface suggesting that the anodic surface processes could be exploited systematically by square wave voltammetry with some advantages in sentivity.

\subsection{Optimization of the Experimental Conditions}

EIS can give information on the impedance changes of the electrode surface with different immersion time. The HAP-modified platinum electrode was dipped into cadmium (II) solution $\left(2.0 \times 10^{-3} \mathrm{~mol} \mathrm{~L}^{-1}\right)$, and then was washed with double distilled water, then put into $0.2 \mathrm{~mol}$ $\mathrm{L}^{-1} \mathrm{KNO}_{3}$ to perform the EIS experiments. The immersion time of the HAP/Pt in Cd(II) solution had great effect on the surface state and the electron-transfer impedance. Figure 7 shows the complex plan diagram of EIS after the modified electrode soaked in $\mathrm{Cd}(\mathrm{II})$ solution at various times, which indicated that the adsorption had an important effect on electron transfer impedance. It can be observed that the diameter of the semicircle decreased to higher frequencies with the increase of adsorption time. When the soaking time in the cadmium solution was over $20 \mathrm{~min}$, there was no drastic change of the interfacial electron-transfer resistance, which meant that the adsorption of $\mathrm{Cd}(\mathrm{II})$ reached a state of saturation. Hence for all subsequent measurements preconcentration time (tp) of 25 min was employed.

The variation of anodic peak current of cadmium versus $\mathrm{pH}$ was investigated (Figure 8). The peak current versus $\mathrm{pH}$ behaviour indicated a variation in sensitivity over the $2.0-10.0 \mathrm{pH}$ range for cadmium (II) studied, and the highest response was achieved at $\mathrm{pH} 5.6$

According to $\mathrm{Wu}$ et al. [35] the main interactions responsible for the surface properties of HAP in aqueous solutions are:

$$
\begin{aligned}
& \equiv \mathrm{PO}^{-}+\mathrm{H}^{+} \leftrightarrow \mathrm{POH}^{0} \\
\equiv & \mathrm{CaOH}^{2+} \leftrightarrow \mathrm{CaOH}^{0}+\mathrm{H}^{+}
\end{aligned}
$$

The positively charged $\mathrm{CaOH}^{2+}$ and neutral $\mathrm{POH}^{0}$, $\mathrm{PO}_{\mathrm{x}} \mathrm{H}_{2}$ and $\mathrm{PO}_{\mathrm{x}} \mathrm{H}$ sites must prevail on HAP surface in acidic solutions [36,37] making surface charge in this $\mathrm{pH}$ region positive and at higher $\mathrm{pH}$ values negative. Cadmium exists in such a solution only in the form of $\mathrm{Cd}^{2+}$ 


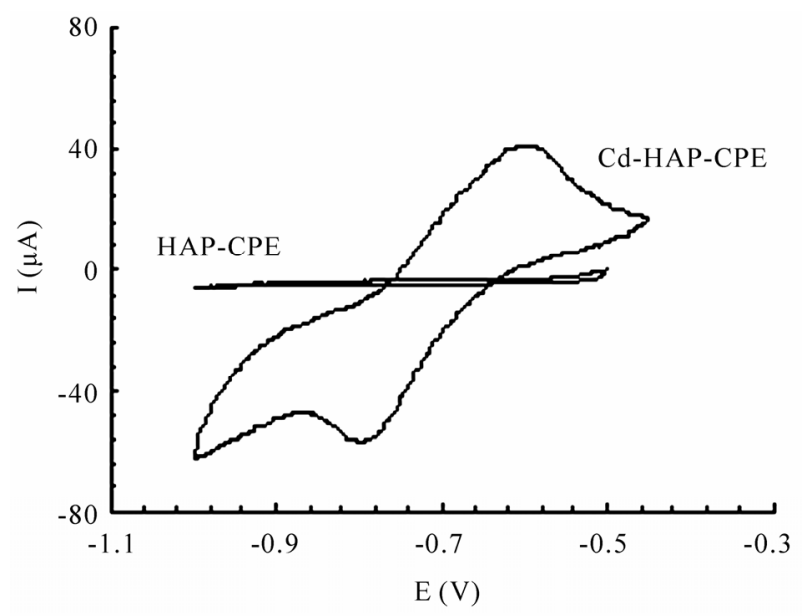

Figure 6. Cyclic voltammogram in $\mathrm{HClO}_{4}(0.1 \mathrm{M})$ for HAP layer at carbon paste electrode (CPE) (a): before preconcentration step (b): after preconcentration in $4.3 \times 10^{-3} \mathrm{~mol}$ $\mathrm{L}^{-1} \mathrm{Cb}(\mathrm{II}), \mathrm{pH}$ 5.6. $\mathrm{V}_{\mathrm{b}}=100 \mathrm{mV} \mathrm{s}^{-1}$, between -0.4 and $-1.0 \mathrm{~V}$.

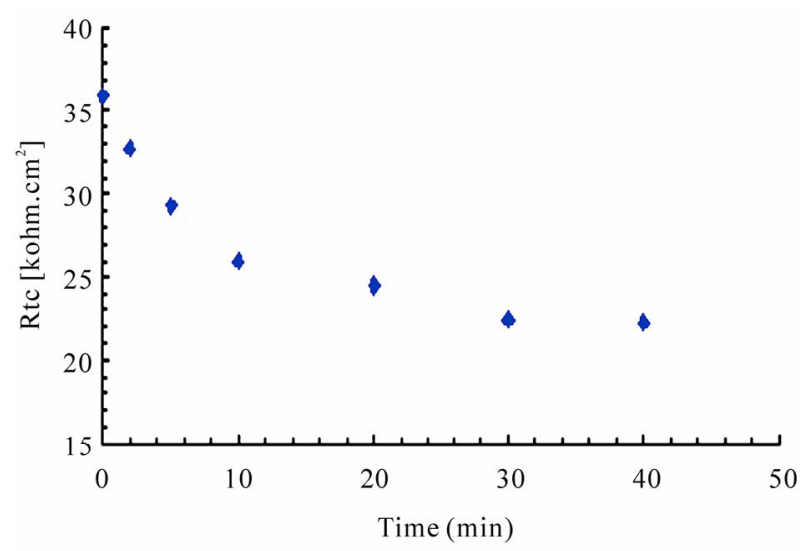

Figure 7. Influence of preconcentration time on charge transfer of $3 \times 10^{-4} \mathrm{~mol} \mathrm{~L}^{-1}$ cadmium (II) in $0.2 \mathrm{~mol} \mathrm{~L}^{-1}$ $\mathrm{KNO}_{3}$, pH 5.6 at $\mathrm{HAP} / \mathrm{Pt}$.

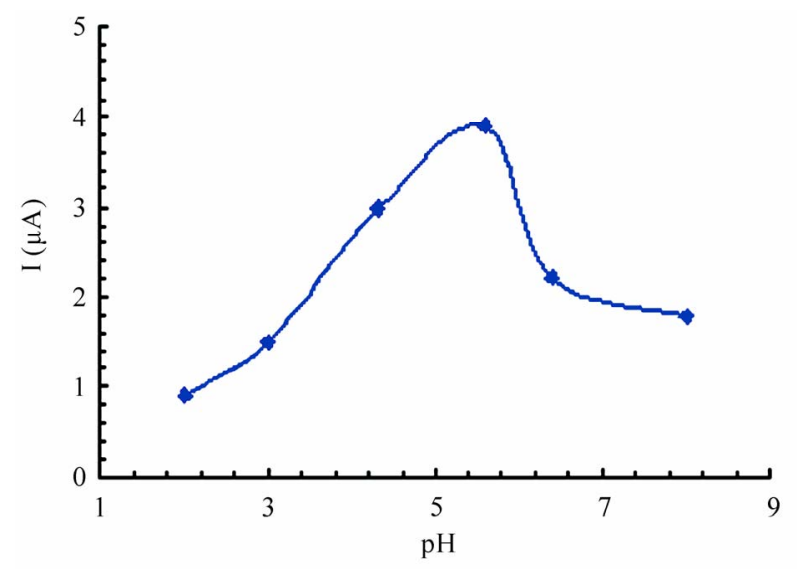

Figure 8. Effect of pH on SWV oxidation peak for $1.3 \times$ $10^{-4} \mathrm{~mol} \mathrm{~L}^{-1}$ cadmium (II) in $0.2 \mathrm{~mol} \mathrm{~L}^{-1} \mathrm{KNO}_{3}$ at $\mathrm{HAP} / \mathrm{Pt}$, tp $=25 \mathrm{~min}$. ions, since no hydrolysis takes place at $\mathrm{pH}$ values lower than 6.0 [38]. Consequently, in acidic solutions where apatite surface is positively charged, $\mathrm{Cd}^{2+}$ could be bound due to ion exchange in accordance with the molar ratio of $\mathrm{Cd}^{2+}$ bound by apatite to $\mathrm{Ca}^{2+}$ released from apatite $[39,40]$.

\subsection{Calibration}

The calibration plot generated using the optimum conditions determined above $\left(\mathrm{pH} 6.5,0.2 \mathrm{~mol} \mathrm{~L}^{-1}\right.$ potassium nitrate, 25 min of accumulation time) is shown in Figure 9. The HAP-modified platinum electrode response was linear up to $20 \mathrm{~mol} \mathrm{~L}^{-1}$ with a sensitivity (slope) of $0.0301 \mu \mathrm{A}$ per $\mu \mathrm{mol} \mathrm{L}^{-1}$ cadmium (II) $\left(R^{2}=0.9969\right)$. The lower detection limit (DL, $3 \sigma$ ) and the quantification limit (QL, $3 \sigma$ ) (defined as five times the standard deviation of the response obtained for a blank) were $8.85 \times$ $10^{-8} \mathrm{~mol} \mathrm{~L}^{-1}$ and $9.35 \times 10^{-7} \mathrm{~mol} \mathrm{~L}^{-1}$ respectively.

Such results are shown to be very appropriate for the determination of ultratraces of cadmium in water samples, where the recommended maximum residue stipulated is $10 \mu \mathrm{g} / \mathrm{Kg}$ [41], indicating that the method could be employed to analyze cadmium (II) in natural water samples.
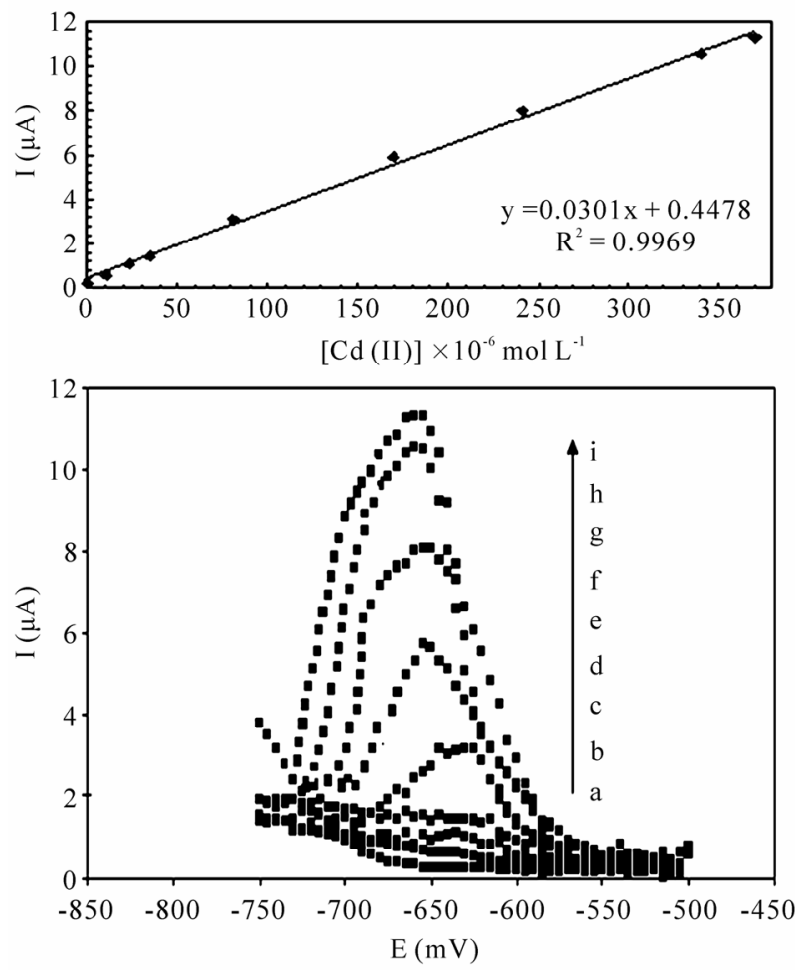

Figure 9. Square-wave voltammograms in $0.2 \mathrm{~mol} \mathrm{~L}^{-1}$ $\mathrm{KNO}_{3}$, pH 5.6, tp = 25 min, at HAP/Pt of cadmium (II); a) $0.2 \times 10^{-6}$, b) $2.2 \times 10^{-6}$, c) $4 \times 10^{-6}$, d) $6 \times 10^{-6}$, e) $9 \times 10^{-6}$, f) 11 $\times 10^{-6} \mathrm{~mol} \mathrm{~L}^{-1}$. 
It should, however, be pointed out that even though the DL and the QL obtained in the present study are comparable to the values obtained in the literature [42]. However, it was higher than those obtained with bismuth film [43]. The detection limit can be improved by optimizing the $\mathrm{Ca} / \mathrm{P}$ ratio of hydroxyapatite. Particularly, the detection limit can be improved significantly by increasing the surface area of the modifier.

The relative standard deviation of eight successive scans was $2.9 \%$ for $2.5 \times 10^{-5} \mathrm{~mol} \mathrm{~L}^{-1}$ cadmium, indicating excellent reproducibility of the modified electrode. In addition, the stability of the modified electrode was investigated. The peak current was daily tested in the $\mathrm{pH}$ 6.5 of $2.5 \times 10^{-5} \mathrm{~mol} \mathrm{~L}^{-1}$ cadmium (II). No apparent decrease in the current response was found over 3 days, and $10 \%$ decrease after 6 days and kept almost constant afterward.

\subsection{Effects of Other Ions}

The presence of other metal ions could interfere with cadmium (II) determination if they compete for adsorption at the HAP sites. Large amounts of alkaline and alkaline earth metal ions have no interference with the microextraction of $\mathrm{Cd}(\mathrm{II})$ under the selected conditions because of their very low stability in the formation of metal-HAP complexes (Figure 10). When the developed procedure was employed, for the determination of $6.3 \times$ $10^{-6} \mathrm{~mol} \mathrm{~L}^{-1} \mathrm{Cd}(\mathrm{II})$ with an accumulation time of $25 \mathrm{~min}$, no interference was found for additions of $6.3 \times 10^{-6} \mathrm{~mol}$ $\mathrm{L}^{-1}$ each of $\mathrm{Cu}^{2+}, \mathrm{Fe}^{3+}, \mathrm{Zn}^{2+}, \mathrm{Ag}^{+}, \mathrm{Pb}^{2+}$ and $\mathrm{Hg}^{2+}$. However $\mathrm{Pb}^{2+}$ interfere significantly by decreasing the $\mathrm{Cd}(\mathrm{II})$ signal, because it can be rapidly adsorbed at HAP surface and prevent the complex formation and accumulation of $\mathrm{Cd}(\mathrm{II})$ at the electrode surface. This is explained by the capacity of adsorption of HAP that varies according to the scale of affinity decreasing: $\mathrm{Pb}>\mathrm{Cd}$.

The Cd sorption can be decomposed in two steps: in the first step a high rate of sorption occurred; in the second step, the sorption was slower before reaching the equilibrium. In the mixture of $\mathrm{Cd}^{2+}$ of $\mathrm{Pb}^{2+}$, competitive uptake among the heavy metals affected retention of $\mathrm{Cd}^{2+}$ by HAP. Competition among the two heavy metals determined reduction of the amount of sorbed Cd(II) by $15 \%$ compared to the single-metal system. This result showed that the uptake behavior of Cd(II) was altered by the competitive effects among the metals in agreement with Chen et al. [44].

\subsection{Application of the Proposed Method in Environmental Samples}

To verify the accuracy of the method, the developed method was applied to the determination of $\mathrm{Cd}(\mathrm{II})$ in natural water samples collected from Oum Er Rbia river, Tadla-Azilal region, Morocco. Apart from the element of interest, the natural waters analyzed contained many other elements (Table 2).

The water samples were used to prepare the electrolytes employed for construction of the new analytical curves and recovery curves by applying the proposed procedure. In this way, the influence of the total components present in natural water samples in the responses obtained for the modified electrode could be evaluated.

Recovery experiments were also carried out in order to evaluate the interference of matrix effects of the natural water samples on the oxidation of cadmium on HAP/Pt. Recovery curves for the samples spiked with $2.0 \times 10^{-5}$ $\mathrm{mol} \mathrm{L}^{-1} \mathrm{Cd}(\mathrm{II})$ were then obtained by the standard addition method. Moreover, the results obtained with HAP/Pt were compared with those obtained with ICP-MS method for spiked river water. The quantification of these samples for both techniques was carried out by the standard addition method. The results of the present study are shown in Table 3. As shown, cadmium concentrations determined by the two techniques are in a very good agreement and no significant differences at the $94 \%$ confidence level were found. The percentage recovered obtained presents satisfactory values for the proposed electroanalytical methods, indicating the suitability of the proposed method for use in natural water samples.

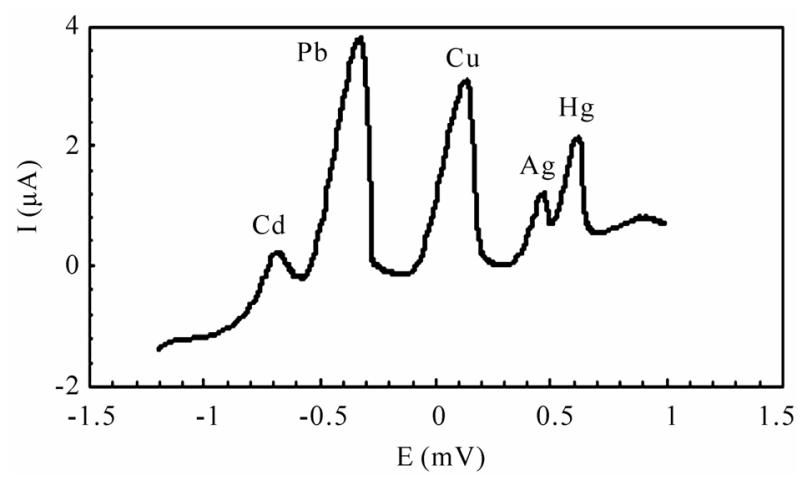

Figure 10. Cyclic voltammogram after exposure to a solution containing $\mathrm{Cd}(\mathrm{II}), \mathrm{Ag}(\mathrm{I}), \mathrm{Cu}(\mathrm{II}), \mathrm{Hg}(\mathrm{II})$, and $\mathrm{Pb}(\mathrm{II})$ of concentration $6.3 \times 10^{-6} \mathrm{~mol} \mathrm{~L}^{-1}$.

Table 2. Physicochemical parameters of used natural water.

\begin{tabular}{cccccccc}
\hline $\mathrm{pH}$ & $\mathrm{MES}\left(\mathrm{mg} \mathrm{L}^{-1}\right)$ & $\mathrm{O}_{2}$ (dissous) $\left(\mathrm{mg} \mathrm{L}^{-1}\right)$ & $\mathrm{NH}_{4}^{+}\left(\mathrm{mg} \mathrm{L}^{-1}\right)$ & $\mathrm{Mn}^{2+}\left(\mathrm{mg} \mathrm{L}^{-1}\right)$ & $\mathrm{NO}_{2}^{-}\left(\mathrm{mg} \mathrm{L}^{-1}\right)$ & $\mathrm{NO}_{3}^{-}\left(\mathrm{mg} \mathrm{L}^{-1}\right)$ & Nitrogen total $\left(\mathrm{mg} \mathrm{L}^{-1}\right)$ \\
\hline 8.85 & 9.5 & 11 & 0.26 & 0.03 & 0.18 & 5.6 & 0.7 \\
\hline
\end{tabular}


Table 3. Results obtained from the linear regression curves for the determination of $\mathrm{Cd}(\mathrm{II})$ at HAP/Pt in natural waters.

\begin{tabular}{lc}
\hline \multicolumn{1}{c}{ Parameters } & Peak \\
\hline Equation & $Y=0.0213 X+0.425$ \\
$R^{2}$ & 0.992 \\
Slope A $\left(\mathrm{mol} \mathrm{L}^{-1}\right)$ & 0.503 \\
Standard deviation $(\sigma)\left(\times 10^{-9} \mathrm{~A}\right)$ & 16.3 \\
Relative standard deviation $(\%)$ & 3.07 \\
Recovery $(\%)(\mathrm{SWV})$ & 94.9 \\
Recovery $(\%)(\mathrm{ICP}-\mathrm{MS})$ & 93.6 \\
\hline
\end{tabular}

\section{Conclusions}

It was shown that one well-defined anodic peak could be obtained at a potential of $-0.74 \mathrm{~V}$ versus $\mathrm{Ag} / \mathrm{AgCl}$, using cyclic and square wave voltammetry. The oxidation of $\mathrm{Cd}$ deposed on HAP/Pt electrode occurs in a reversible system. Optimization of the experimental conditions for square wave voltammetry yielded a detection limit for cadmium (II) of $8.85 \times 10^{-8} \mathrm{~mol} \mathrm{~L}^{-1}$ much better than that described in the literature and this sensor shows a wide linear response range, good sensitivity and reproducibility.

\section{References}

[1] R. K. Srivastav, S. K. Gupta, K. D. P. Nigam and P. Vasudevan, "Treatment of Chromium and Nickel in Wastewater by Using Aquatic Plants," Water Research, Vol. 28, No. 7, July 1994, pp. 1631-1638.

[2] P. J. Apostoli, "Elements in Environmental and Occupational Medicine," Journal of Chromatography B, Vol. 778, No. 1, October 2002, pp. 63-97.

[3] M. G. R. Vale, M. M. Silva, B. Welz and É. C. Lima, "Determination of Cadmium, Copper and Lead in Mineral Coal Using Solid Sampling Graphite Furnace Atomic Absorption Spectrometry," Spectrochimica Acta B: Atomic Spectroscopy, Vol. 56, No. 10, 2001, pp. 1859-1873.

[4] E. B. Bulska, M. Walcerz, W. Jedral and A. Hulanick, "On-Line Preconcentration of Lead and Cadmium for Flame Atomic Absorption Spectrometry Using a Flow-through Electrochemical Microcell," Analytica Chimica Acta, Vol. 357, No. 1-2, December 1997, pp. 133-140.

[5] M. W. Wensing, D. Y. Liu, B. W. Smith and J. D. Winefordner, "Determination of Lead in Whole Blood Using a Capacitively Coupled Wave Plasma Atomic Emission Spectrometer," Analytica Chimica Acta, Vol. 299, No. 1, December 1994, pp. 1-7.

[6] N. Cardellicchio, S. Cavalli and J. M. Riviello, "Deter- mination of Cadmium and Lead at $\mu \mathrm{g} / 1$ Levels in Aqueous Matrices by Chelation Ion Chromatography," Journal of Chromatography A, Vol. 640, No. 1-2, 1993, pp. 207-216.

[7] B. Paull, M. Foulkes and P. Jones, "High-Performance Chelation Ion Chromatographic Determination of Trace Metals in Coastal Sea-Water Using Dye-Impregnated Resins," Analyst, Vol. 119, No. 5, 1994, pp. 937-941.

[8] D. Dragoe, N. Spataru, R. Kawasaki, A. Manivannan, T. Spataru, D. Tryk and A. Fujishima, "Detection of Trace Levels of $\mathrm{Pb}^{2+}$ in Tap Water at Boron-Doped Diamond Electrodes with Anodic Stripping Voltammetry," Electrochimica Acta, Vol. 51, No. 12, 2006, pp. 2437-2441.

[9] S. Laschi, I. Palchetti and M. Mascini, "Gold-Based Screen-Printed Sensor for Detection of Trace Lead," Sensors and Actuators B: Chemical, Vol. 114, No. 1, March 2006, pp. 460-465.

[10] J. M. Zen and S. Y. Huang, "Square-Wave Voltammetric Determination of $\operatorname{Lead}(\mathrm{II})$ with a Nafion ${ }^{\circledR} / 2,2$-Bipyridyl Mercury Film Electrode," Analytica Chimica Acta, Vol. 296, No. 1, September 1994, pp. 77-86.

[11] V. Rehacek, I. Hotovy and M. Vojs, "Bismuth-Coated Diamond-Like Carbon Microelectrodes for Heavy Metals Determination," Sensors and Actuators B: Chemical, Vol. 127, No. 1, October 2007, pp. 193-197.

[12] M. Ghiaci, B. Rezaei and R. J. Kalbasi, "High Selective $\mathrm{SiO}_{2}-\mathrm{Al}_{2} \mathrm{O}_{3}$ Mixed-Oxide Modified Carbon Paste Electrode for Anodic Stripping Voltammetric Determination of $\mathrm{Pb}$ (II)," Talanta, Vol. 73, No. 1, August 2007, pp. 37-45.

[13] L. Y. Cao, J. B. Jia and Z. H. Wang, "Sensitive Determination of $\mathrm{Cd}$ and $\mathrm{Pb}$ by Differential Pulse Stripping Voltammetry with in situ Bismuth-Modified Zeolite Doped Carbon Paste Electrodes," Electrochimica Acta, Vol. 53, No. 5, January 2008, pp. 2177-2182.

[14] K. Kalcher, "Chemically Modified Carbon Paste Electrodes in Voltammetric Analysis," Electroanalysis, Vol. 2, No. 6, August 1990, pp. 419-433.

[15] K. Kalcher, J. M. Kauffmann, J. Wang, I. Svancara, K. Vytras, C. Neuhold and Z. Yang, "Sensors Based on Carbon Paste in Electrochemical Analysis: A Review with Particular Emphasis on the Period 1990-1993," Electroanalysis, Vol. 7, No. 1, January 1995, pp. 5-22.

[16] S. C. C. Monterroso, H. M. Carapuça, J. E. J. Simão and A. C. Duarte, "Optimisation of Mercury Film Deposition on Glassy Carbon Electrodes: Evaluation of the Combined Effects of $\mathrm{pH}$, Thiocyanate Ion and Deposition Potential," Analytica Chimica Acta, Vol. 503, No. 2, February 2004, pp. 203-212.

[17] H. M. Carapuc, S. C. C. Monterroso, L. S. Rocha and A. C. Duarte, "Simultaneous Determination of Copper and Lead in Seawater Using Optimised Thin-Mercury Film Electrodes in situ Plated in Thiocyanate Media," Talanta, Vol. 64, No. 2, October 2004, pp. 566-569.

[18] A. Merkoçi, U. Anik-Kirkoz and S. Alegret, "Procedure 7 Determination of Lead and Cadmium in Tap Water and Soils by Stripping Analysis Using Mercury-Free Graphite-Epoxy Composite Electrodes," Comprehensive Analytical Chemistry, Vol. 49, August 2007, pp. e47-e52. 
[19] A. Denzli, B. Garipcan, S. Emir, S. Patir and R. Say, "Heavy Metal Ion Adsorption Properties of Methacrylamidocysteine-Containing Porous Poly (Hydroxyethyl Methacrylate) Chelating Beads," Adsorption Science and Technology, Vol. 207, No. 7, 2002, pp. 607-617.

[20] E. Deydier, R. Guilet and P. Sharrock, "Beneficial Use of Meat and Bone Meal Combustion Residue: 'An Efficient Low Cost Material to Remove Lead from Aqueous Effluent'," Journal of Hazardous Materials, Vol. 101, No. 1, July 2003, pp. 55-64.

[21] K. Mori, K. Yamaguchi, T. Hara, T. Mizugaki, K. Ebitani and K. Kaneda, "Controlled Synthesis of HydroxyapatiteSupported Palladium Complexes as Highly Efficient Heterogeneous Catalysts," Journal of the American Chemical Society, Vol. 124, No. 39, 2002, pp. 11572-11573.

[22] T. Suzuki, T. Hatsushika and M. Michihiro, "Synthetic Hydroxyapatites as Inorganic Cation Exchangers. Part 2," Journal of the Chemical Society, Faraday Transactions, Vol. 1, No. 78, 1982, pp. 3605-3611.

[23] Q. Y. Ma, T. J. Logan, S. J. Traina and J. A. Ryan, "Effects of Aqueous Al, Cd, Cu, Fe(II), Ni, and $\mathrm{Zn}$ on $\mathrm{Pb}$ Immobilization by Hydroxyapatite," Environmental Science \& Technology, Vol. 28, No. 7, July 1994, pp. 1219-1228.

[24] Y. Xu, F. W. Schwartz and S. J. Traina, "Sorption of $\mathrm{Zn}^{2+}$ and $\mathrm{Cd}^{2+}$ on Hydroxyapatite Surfaces," Environmental Science \& Technology, Vol. 28, No. 8, August 1994, pp. $1472-1480$.

[25] A. G. Leyva, J. Marrero, P. Smichowski and D. Cicerone, "Sorption of Antimony onto Hydroxyapatite," Environmental Science \& Technology, Vol. 35, No. 18, August 2001, pp. 3669-3675.

[26] J. A. G. del Río, P. J. Morando and D. S. Cicerone, "Natural Materials for Treatment of Industrial Effluents: Comparative Study of the Retention of Cd, Zn and Co by Calcite and Hydroxyapatite. Part I: Batch Experiments," Journal of Environmental Management, Vol. 71, No. 2, June 2004, pp. 169-177.

[27] M. Peld, K. Tõnsuaadu and V. Bender, "Sorption and Desorption of $\mathrm{Cd}^{2+}$ and $\mathrm{Zn}^{2+}$ Ions in Apatite-Aqueous Systems," Environmental Science \& Technology, Vol. 38, No. 21, September 2004, pp. 5626-5631.

[28] A. Corami, S. Mignardi and V. Ferrini, "Copper and Zinc Decontamination from Single- and Binary-Metal Solutions Using Hydroxyapatite," Journal of Hazardous Materials, Vol. 146, No. 1-2, July 2007, pp. 164-170.

[29] I. Smiciklas, S. Dimovic, I. Plecaš and M. Mitric, "Removal of $\mathrm{Co}^{2+}$ from Aqueous Solutions by Hydroxyapatite," Water Research, Vol. 40, No. 12, 2006, pp. 2267-2274.

[30] A. Yasukawa, T. Yokoyama, K. Kandori and T. Ishikawa, "Reaction of Calcium Hydroxyapatite with $\mathrm{Cd}^{2+}$ and $\mathrm{Pb}^{2+}$ ions," Colloids and Surfaces A: Physicochemical and Engineering Aspects, Vol. 299, No. 1-3, 2007, pp. 203-208.

[31] R. R. Sheha, "Sorption Behavior of Zn(II) Ions on Synthesized Hydroxyapatites," Journal of Colloid and Interface Science, Vol. 310, No. 1, June 2007, pp. 18-26.

[32] M. A. El Mhammedi, M. Achak, M. Bakasse and A. Chtaini, "Physico-Chemical Characterization of Electrochemical
Deposit of $\mathrm{Ca}_{10}\left(\mathrm{PO}_{4}\right)_{6}(\mathrm{OH})_{2}$ on Copper Surfaces," Applied Surface Science, Vol. 253, No. 14, May 2007, pp. 5925-5930.

[33] Hydroxyapatite $\left[\mathrm{Ca}_{5}(\mathrm{PO} 4)_{3}(\mathrm{OH})\right]$ Joint Committee on Powder Diffraction Standards, Card No. 09-432.

[34] T. Tsurus and S. Haruyama, "Corrosion Monitor Based on Impedance Method. II. Construction and Its Application to Homogeneous Corrosion," Journal of Japan Society of Corrosion Engineering. Vol. 27, 1978, pp. 573-579.

[35] L. Wu, W. Forsling and P. W. Schindler, "Surface Complexation of Calcium Minerals in Aqueous Solution: 1. Surface Protonation at Fluorapatite-Water Interfaces," Journal of Colloid and Interface Science, Vol. 147, No. 1, November 1991, pp. 178-185.

[36] M. Jarlbring, D. E. Sandstrom, O. N. Abtzukin and W. Forsling, "Characterization of Active Phosphorus Surface Sites at Synthetic Carbonate-Free Fluorapatite Using Single-Pulse ${ }^{1} \mathrm{H},{ }^{31} \mathrm{P}$, and ${ }^{31} \mathrm{P} \mathrm{CP}$ MAS NMR," Langmuir, Vol. 22, No. 10, May 2006, pp. 4787-4792.

[37] E. Sandstrom, M. Jarlbring, O. N. Abtzukin and W. Forsling, "A Spectroscopic Study of Calcium Surface Sites and Adsorbed Iron Species at Aqueous Fluorapatite by Means of ${ }^{1} \mathrm{H}$ and ${ }^{31} \mathrm{P}$ MAS NMR," Langmuir, Vol. 22, No. 26, December 2006, pp. 11060-11064.

[38] I. D. Smiciklas, S. K. Milonjic, P. Pfendt and S. Raicevic, "The Point of Zero Charge and Sorption of Cadmium (II) and Strontium (II) Ions on Synthetic Hydroxyapatite," Separation and Purification Technology, Vol. 18, No. 3, May 2000, pp. 185-194.

[39] Y. Takeuchi, T. Suzuki and H. Arai, "A Study of Equilibrium and Mass Transfer in Processes for Removal of Heavy-Metal Ions by Hydroxyapatite," Journal of Chemical Engineering of Japan, Vol. 21, No. 1, February 1988, pp. 98-100.

[40] J. Jeanjean, S. McGrellis and J. C. Rouchaud, "A Crystallographic Study of the Sorption of Cadmium on Calcium Hydroxyapatites: Incidence of Cationic Vacancies," Academic Press Inc., Cambridge, Vol. 126, November 1996, pp. 195-201.

[41] B. O. Fowler, "Infrared Studies of Apatites. I. Vibrational Assignments for Calcium, Strontium, and. Barium Hydroxyapatites Utilizing Isotopic Substitution," Inorganic Chemistry, Vol. 13, No. 1, January 1974, pp. 194-207.

[42] C. Hu, K. Wu, X. Dai and S. Hu, "Simultaneous Determination of Lead(II) and Cadmium(II) at a Diacetyldioxime Modified Carbon Paste Electrode by Differential Pulse Stripping Voltammetry," Talanta, Vol. 60, No. 1, May 2003, pp. 17-24.

[43] C. Kokkinos, A. Economou, I. Raptis and C. E. Efstathiou, "Lithographically Fabricated Disposable Bismuth-Film Electrodes for the Trace Determination of $\mathrm{Pb}$ (II) and Cd(II) by Anodic Stripping Voltammetry," Electrochimica Acta, Vol. 53, No. 16, June 2008, pp. 5294-5299.

[44] X. Chen, J. V. Wright, J. L. Conca and L. M. Peurrung, "Effects of $\mathrm{pH}$ on Heavy Metal Sorption on Mineral Apatite," Environmental Science \& Technology, Vol. 31, No. 3, February 1997, pp. 624-631. 